\title{
Study of Microwave Technique in Hot Pepper Seed by Different Solvents with an Assessing Antioxidant and Antibacterial Properties
}

\author{
Holem H. Balaky ${ }^{1,2^{*}}$, Yaseen Galali3,4, Eyyüp Karaoğul ${ }^{5}$, Ertuğrul altuntaş ${ }^{6}$, Nabil Hussain Rasul ${ }^{3}$, \\ Adnan Ali Mustafa ${ }^{7}$ \\ ${ }^{1}$ Department of General Science, Faculty of Education, Soran University, Soran, Kurdistan Region, Iraq, ${ }^{2}$ Department of Bioengineering and \\ Sciences, Kahramanmaraş Sütçü Imam University, Turkey, ${ }^{3}$ Department Food Technology, College of Agricultural Engineering Sciences, \\ Salahaddin University, Erbil, Kurdistan Region, Iraq, ${ }^{4}$ Department of Nutrition and Dietetics, Cihan University, Erbil, Kurdistan Region, Iraq, \\ ${ }^{5}$ Department of Food Engineering, Harran University, Sanliurfa, Turkey, ${ }^{6}$ Kahramanmaras Sutcu Imam University, Forest Faculty, Forest \\ Industry Engineering, Kahramanmaras, Turkey, ${ }^{7}$ Department of Food Science, Ministry of Agriculture and Water Resources, Erbil, Kurdistan \\ Region, Iraq
}

\section{*Corresponding author: Holem H. Balaky, \\ Department of General Science, Faculty of Education, Soran University, Soran, Kurdistan Region, Iraq. \\ E-mail: holem.rasul@gsci. soran.edu.iq}

Received: 10 December 2020 Accepted: 09 March 2021 Published: 30 June 2021

\section{DOI}

10.25156/ptj.v11n1y2021.pp80-86

\section{A B S T R A C T}

Chili pepper seed (CPS) is rich in nutrients and phytochemical particularly oil which could possess antimicrobial and antioxidant properties. CPS was extracted with water and ethanol and assessed for anti-oxidants activity through assessing total tannin, total phenol, total flavonoid and total anthocyanin and antimicrobial properties through assessing inhibition zone and minimum inhibitory concentration. Both yield extraction and total anthocyanin values of oil extracted with water were 38.4 and $40.075 \%$, respectively, and are significantly $(P<0.01)$ higher than ethanolic extraction. On the other hand, total tannin, total phenol, and total flavonoid values were $0.0575,1.80700$, and $0.26350 \mu \mathrm{M}$, respectively, which were significantly $(P<0.01)$ higher with ethanol extraction. Ethanol had the greater free radical scavenging activity (IC $50 \mu \mathrm{g} / \mathrm{ml}$ ) and more close standard butylated hydroxytoluene. Antimicrobial results indicated that water extracts were more effective against Staphylococcus aureus Pseudomonas aeruginosa, Enterococcus faecalis, Enterobacter aerogenes up to $24 \mathrm{~mm}$ inhibition zone, but it is dose dependent. CPS oil extracts could be used as source of antimicrobial and antioxidants compounds with the aid of microwave-assisted extraction. Ethanol has better yield and anthocyanin extraction and free radical, whereas water extraction has effective antimicrobial activity.

Keywords: Chili pepper seed oil; Microwave-assisted-extraction; Antioxidant; Antibacterial activity; Chili pepper

\section{INTRODUCTION}

Chili pepper (CP) (Capsicum annum L.) is a very common and widely utilized herb for different purposes including seasoning, flavoring, imparting aroma, colorant, and pungent products (Arslan and Özcan, 2011; Omolo et al., 2014; Korkutata and Kavaz, 2015). CP can be grown commonly in various areas of the world particularly in cultivated tropical and temperate parts (Zou et al., 2015; Arslan and Özcan, 2011). CP possesses various of applications, including nutraceuticals, natural coloring material, and cosmetic usages (Di Cagno et al., 2009, Chen et al., 2012; Omolo et al., 2014). This is due to the fact that CP possesses various phytochemicals including compounds such as carotenoids (Di Scala and Crapiste 2008; Vega-Gálvez et al., 2009), and polyphenols, particularly flavonoids.

CP seeds (CPS) are separated and used for animal feed; however, they are largely discarded to environment and causes pollution (Jarret et al., 2013). CPS is attained as waste processed products in the preparation of red pepper color and powder and estimated to be around $450-500 \mathrm{~g} / 1 \mathrm{~kg}$ of the total pepper weight (Wang et al., 2014, Gu et al., 2017). Food processed waste contains many biologically active compounds with pharmaceutical and nutraceutical properties (Galali et al., 2020). CPS contain fatty acids, which majorly composed of linoleic acid, oleic acid, hexadecanoic acid, stearic acid, and linolenic acid (Jinyan et al., 2014; Yilmaz et al., 2015), and also high in anti-oxidants (Özyildiz et al., 2012). In addition, increases in the conjugated diene and triene contents indicate the accelerated oxidation reactions at high temperatures (Balaky and İnanç, 2014; Holem et al., 2020).

Different extraction techniques have been developed to extract various phytochemicals from plants including microwave-assisted extraction (MAE), enzymes-assisted extraction, and ultrasound-assisted extraction. MAE is 
of particular interest since it possesses superiority over conventional methods since it requires shorter time, using lower heat for extraction and finally yields better quality of compounds due to fewer breakdowns as a thermal process. Furthermore, since MAE is compatible with water to be used for extraction, this leads to use less organic solvents, on the one hand and on the other hand, imparts a chance to extract medium and non-polar compounds from plant based products (Li et al., 2017).

Furthermore, using MAE technique allows researchers to couple sample preparation method to some sophisticated methods such as GC-MS and HPLC to obtain rapid and reliable determination of compounds (Xie et al., 2017).

The purpose of this study was to evaluate antioxidants and antibacterial activities of the CPS oil extracts using both water and ethanol solvents with MAE as a novel technique in relation aforementioned activities.

\section{MATERIAL AND METHODS}

\section{Plant Collection and Plant Powdering}

The aerial part plant of the species of bibber was collected from Müsan Food Inc. The plants sample was grounded using new modern grinder YAZICILAR (Model GI, Capacity/hour $15 \mathrm{Kg}$, Capacity 5 letter, Speed 13000 rpm, and Cycle $500 \mathrm{~g})$. The plants' powders then were kept in plastic bags in refrigerator at $4^{\circ} \mathrm{C}$ for further studies.

\section{Preparation of Plant Extract}

The powdered was weighed and mixed with different solvents (distilled water and Ethanol) with the aid of microwave for $3 \mathrm{~min}$ after boiling point. The extracted mixtures then were separately evaporated using Fume Hood for $24 \mathrm{~h}$.

\section{Yield Determination}

The yield percentage of the extract was determined using the following formula: (Murugan and Parimelazhagan 2014, Holem et al., 2020).

Equation 1: extract percentage yield

$$
\text { Yeild Extraction }(\%)=\frac{X}{Y} * 100
$$

Where,

$\mathrm{X}$ is the oven dry weight of extract $(\mathrm{g})$, $\mathrm{Y}$ is the oven dry weight of the sample $(\mathrm{g})$.

\section{Determination of Total Condensed Tannins}

Total condensed tannins were determined using Ultravioletvisible (UV-vis) spectrophotometer. Extraction solution was prepared by mixing $0.05 \mathrm{~g}$ of $\mathrm{Fe}_{2} \mathrm{SO}_{4}, 95 \mathrm{ml}$-butanol and $5 \mathrm{ml} \mathrm{HCl}(35 \%)$. For determining the condensed tannin, $0.01 \mathrm{~g}$ of crude plant and mimosa tannin put separately in a test tubes and $10 \mathrm{ml}$ of the prepared extraction solution were added and placed in water bath for heating for $1 \mathrm{~h}$. The absorbance was read at $580 \mathrm{~nm}$ wavelength (Makkar and Singh 1995).

\section{Determination of Total Phenolic Compounds}

The total phenolic compounds were quantified following Folin-Ciocalteu method as described by Dewanto et al. (2002). An aliquot of diluted extract was added to $180 \mathrm{~mL}$ of distilled water and $20 \mathrm{~mL}$ of Folin-Ciocalteu reagent. The mixture was then shaken and allowed to stand for 6 min before adding $1.60 \mathrm{~mL}$ of $7 \% \mathrm{Na}_{2} \mathrm{CO}_{3}$. The solution was then adjusted with distilled water to a reach a volume of $3 \mathrm{~mL}$ and thoroughly mixed. After incubation in the dark, absorbance at $760 \mathrm{~nm}$ was read against the blank. The total phenol content of CPS extract was expressed as milligrams of Gallic acid equivalents per gram of dry weight (mg GAE/g DW) from a calibration curve with Gallic acid. All samples were analyzed in three triplicate (Dewanto et al., 2002).

\section{Determination of Flavonoid Contents}

The flavonoid contents were determined using calorimetric method following (Arvouet-Grand et al., 1994). An aliquot of $1 \mathrm{~mL}$ of extract solution $(25-200 \mu \mathrm{g} / \mathrm{mL})$ or quercetin (25-200 $\mu \mathrm{g} / \mathrm{mL}$ ) were mixed with $6.4 \mathrm{~mL}$ distilled water, and then $0.3 \mathrm{~mL}$ of $10 \%(\mathrm{w} / \mathrm{v}) \mathrm{AlCl} 3$ was added with $0.3 \mathrm{~mL}(1 \mathrm{M}) \mathrm{CH}_{3} \mathrm{CO}_{2} \mathrm{~K}$. After that, $2 \mathrm{ml}$ of $\mathrm{NaOH}$ was added; and then the solution was then incubated for $30 \mathrm{~min}$ at ambient temperature. The absorbance was read at $510 \mathrm{~nm}$ against the control. The data are expressed milligrams quercetin per gram (mg QE/g) of dry extract.

\section{Total Anthocyanin Content}

Total anthocyanin was determined following the method described previously (Rapisarda et al., 1999) with some amendment. The extract was mixed with buffer solution of $\mathrm{pH} 1.0(0.02 \mathrm{M} \mathrm{KCl}$ and $980 \mathrm{ml}$ of distilled water with $1.86 \mathrm{~g} \mathrm{KCl}$, with added $27 \mathrm{M} \mathrm{HCl}$ ), and buffer solution of $\mathrm{pH} 4.5$ (960 ml of distilled water with 54,43g sodium acetate, with added $20 \mathrm{M} \mathrm{HCl}$ ) added, respectively. The prepared mixture was homogenized and centrifuged twice during $15 \mathrm{~min}$ at $4^{\circ} \mathrm{C}$ at $5000 \mathrm{rpm}$; the absorbance was read at $512 \mathrm{~nm}$ and $700 \mathrm{~nm}$. The anthocyanin was quantified following the spectrophotometric technique suggested; and the concentration of anthocyanin was specified stratify the Lambert-Beer law. The recorded of spectra in a $\mathrm{He} \lambda$ ios spectrophotometer were amount at $25^{\circ} \mathrm{C}$, total anthocyanin amount was determined by the following formula (Rapisarda et al., 1999). 
The concentration $(\mathrm{mg} / \mathrm{L})$ of every anthocyanin was measured according to the following:

$$
\mathrm{A}=\left(\mathrm{A}^{*} \mathrm{MV}^{*} \mathrm{DF}^{*} 1000\right) /(\in * 1)
$$

Where

$\mathrm{A}:$ is the absorbance $=(\mathrm{A} \lambda$ vis $-\max ) \mathrm{pH} 1.0-(\mathrm{A} \lambda$ vis $-\max )$ $\mathrm{pH} 4.5$

MW is the molecular weight $(\mathrm{g} / \mathrm{mol})=449.2 \mathrm{~g} / \mathrm{mol}$ for Cy-3-glc,

DF: is the dilution factor $(0.2 \mathrm{ml}$ sample is diluted to $2 \mathrm{ml}, \mathrm{DF}=100)$, and $\varepsilon$ is the extinction coefficient $\left(\mathrm{L} \times \mathrm{cm}^{-1} \times \mathrm{mol}-1\right)=26,900$ for $\mathrm{Cy}$-3-glc, where L(path length in $\mathrm{cm})=1$. For comparison, the same extinction coefficient was used for other standards to calculate the concentration of each anthocyanin and thus results reported are expressed as $\mathrm{Cy}-3$ glc equivalents.

\section{Measurement of Antioxidant Activities of Plant Extracts Compounds Using 1,1-Diphenyl-2-picrylhydrazyl (DPPH) Assay}

Antioxidant activity was determined with DPPH assay with some adjustment. DPPH reagent was prepared with 0.1 $\mathrm{mM}$ solubilized in ethanol. Then, the series of $0.1,0.2$, and $0.3 \mathrm{ml}$ of extracts were put in test tubes and ethanol was added to complete $3 \mathrm{ml}$. A quantity of $1 \mathrm{ml}$ of DPPH was then added to the mixture and shaken vigorously. The tubes were then stored for $30 \mathrm{~min}$ in dark room. The absorbance was read using Shimadzu UV-VIS 1240 spectrophotometer at $517 \mathrm{~nm}$. Butylated hydroxyl toluene (BHT) was used as a standard. Free-radical scavenging activity was calculated using following equation described by (Hamad et al., 2017), (Gülçin et al., 2010).

Inhibition of DPPH radical scavenging activity (\%)

$$
=\frac{(A-B)}{A} \times 100
$$

Where:

A: The absorbance of DPPH.

B: The absorbance in the existence of sample and BHT.

\section{Antibacterial Susceptibility Assessment}

The antibacterial activity was assessed using disk diffusion method on Mueller-Hinton agar. Media was prepared by mixing (21 g), of Mueller-Hinton broth with $1000 \mathrm{ml}$ of distilled water. The prepared media was sterilized in autoclaved for $15 \mathrm{~min}$ at $121^{\circ} \mathrm{C}$. After that, the media were used in the disk diffusion method, known as the Kirby-Bauer method (Cruz et al., 2006). Inoculum of $24 \mathrm{~h}$ culture was swabbed on the plate using cotton swab. Disks were struck on each plate using sterile borer.
Different plant extract concentrations $(50,70$, and $100 \mu \mathrm{g} / \mathrm{ml})$ were added to the wells. The plates were incubated for $24 \mathrm{~h}$ at $37^{\circ} \mathrm{C}$. After that, the antibacterial activity was determined by measuring the diameter of inhibited zone ( $\mathrm{mm}$ ).

\section{Identification of Minimum Inhibitory Concentration (MIC)}

In microbiology, the MIC is the lowest concentration of an antimicrobial that inhibits the visible growth of a microorganism after overnight incubation (Kaya et al., 2012). Bacterial suspensions were adjusted to the logarithmic-phase growth to match the turbidity of a $0.5 \mathrm{McF}$ arland standard, yielding approximately $10^{8} \mathrm{CFU} / \mathrm{mL}$ (Cruz et al., 2006). The same amounts of bacteria were added to all tubes to extracts concentration from 500 to $0.9 \mu \mathrm{g} / \mathrm{ml}$, and the tubes were incubated at $37^{\circ} \mathrm{C}$ for $24 \mathrm{~h}$. Each tube was examined for growth and compared to the control. The tubes containing boric acid and borax with nutrient broth were utilized as positive bacterial growth and tubes without nutrients broth used were used as negative bacterial growth. The presence of no growth was considered as antibacterial activity (Yilmaz, 2012).

\section{Statistical Analysis}

All of the statistical parameter calculated using (IBM SPSS) for Windows, version 20, the obtained values were presented as means \pm S.E were calculated. The results of the two groups were compared using the analysis of independent-samples $t$-test. A probability value of $P<0.01$ was adopted as the criteria for significant difference.

\section{RESULTS AND DISCUSSION}

Data from Table 1 and Figure 1 show the yield extraction, total tannin, total phenol, total flavonoid, and total anthocyanin of depends on the types of solvent and its polarity. It can be clearly seen the both yield extraction and total anthocyanin values extracted with water were 38.4 and $40.075(\mathrm{mg} / \mathrm{l})$, respectively, and are significantly $(P<0.01)$ higher than ethanolic extraction. On the other hand, total tannin, total phenol, and total flavonoid values were 0.0575 (mg catechin/g dry), 1.80700 (mg GAE/g D.W.), and 0.26350 (mg QE/g), respectively, which were significantly $(P<0.01)$ higher with ethanol extraction. These results were in agreement with the previous studies when studied the influence of water and ethanol extraction with MAE in plant seeds (Kothari et al., 2012; Holem et al., 2020; Holem et al., 2021). It is also found that ethanol was more powerful in extracting Polyphenol, tannin sand flavonoids comparing to water. This might be due to polarity of solvents which connected to the compounds (Medini et al., 2014). It has been reported that the recovery of phytochemicals in particular polyphenols are driven by 


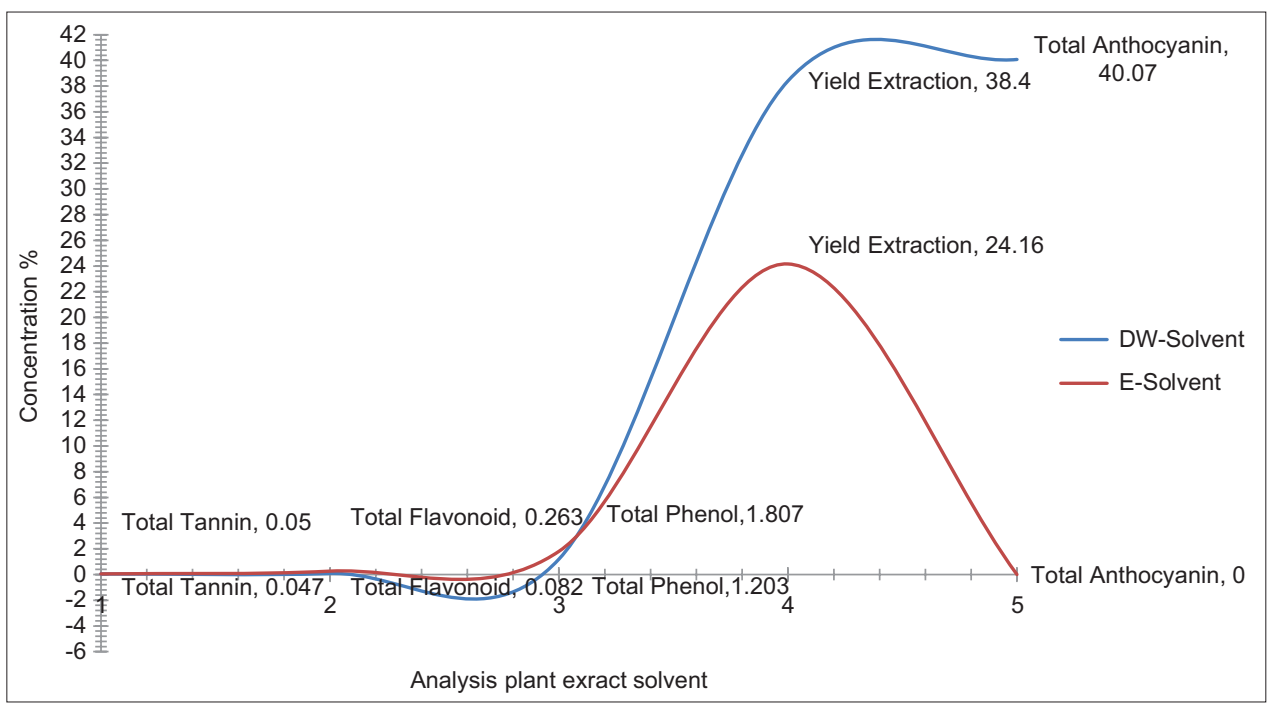

Figure 1: Analysis of plant solvents, yield extraction, total tannin, total phenolic, total flavonoid, and total anthocyanin content of chill pepper

Table 1: Extraction yield, total phenolic, total flavonoid, total tannin, and total anthocyanin content of Chill pepper solvent extracts with MAE

\begin{tabular}{|c|c|c|c|c|c|c|}
\hline \multirow[b]{3}{*}{ Parameters } & \multicolumn{6}{|c|}{ Microwave assisted extraction } \\
\hline & \multicolumn{3}{|c|}{ DW-solvent } & \multicolumn{3}{|c|}{ E-solvent } \\
\hline & Mean \pm S.E & $t$-test & Sig. (0.01) & Mean $\pm S . E$ & $t$-test & Sig. (0.01) \\
\hline Yield extraction (\%) & $38.4000 \pm 0.00000$ & 21499 & 0.000 & $24.1600 \pm 0.00000$ & 21499 & 0.000 \\
\hline Total tannin (mg catechin/g dry) & $0.04750 \pm 0.00028$ & 608.000 & 0.000 & $0.05750 \pm 0.00064$ & 608.000 & 0.000 \\
\hline Total phenol (mg GAE/g DW) & $1.20325 \pm 0.00047$ & $-14.142-$ & 0.000 & $1.80700 \pm 0.0000$ & $-14.142-$ & 0.000 \\
\hline Total flavonoid (mg QE/g) & $0.08250 \pm 0.00028$ & $-1261.193-$ & 0.000 & $0.26350 \pm 0.00064$ & $-1261.193-$ & 0.000 \\
\hline Total anthocyanin (mg/L) & $40.07500 \pm 0.0064$ & $-255.973-$ & 0.000 & N.D. & $-255.973-$ & N.D. \\
\hline
\end{tabular}

Independent-samples $t$-test significantly different $(P<0.01)$, values are Mean \pm SE of Triplicate Samples. N.D.: Not detected, DW: Distilled water, E: Ethanol

a number of factors such as degree of polymerization of phenolic compounds, the type of solvent, and the potent of phenolic compounds phenolic compounds to produce complex with the high degree of insolubility with other plant constituents (Gálvez et al., 2005).

\section{Free-radical Scavenging of DPPH Antioxidant}

Free-radical scavenging ability results of both water and ethanol solvents with three different concentrations in comparison to BHT are shown in Tables 2 and 3. It can be seen that with increasing concentration from 0.1 to 0.3 , the free-radical scavenging ability of water extracts is increasing from $50.69(\mu \mathrm{g} / \mathrm{ml})$ to $70.69(\mu \mathrm{g} / \mathrm{ml})$ and ethanol extracts from $79.86(\mu \mathrm{g} / \mathrm{ml})$ to $86.57(\mu \mathrm{g} / \mathrm{mL})$. Therefore, scavenging ability is reversibly correlated increasing extract concentration. Furthermore, it can also be noticed that with ethanol, the extraction has more free radical scavenging ability and more close the standard BHT comparing to water [Figures 2 and 3]. This was also confirmed by IC50 which represents the potency of the extracts to needed to bring down DPPH radicals to $50 \%$. Ethanol extracts IC50 performed better and showed
Table 2: Free-radical scavenging activity, expressed as median inhibitory concentration $(\mu \mathrm{g} / \mathrm{ml})$, in the DPPH test with CPS extracts against BHT

\begin{tabular}{|c|c|c|c|c|}
\hline \multirow{2}{*}{$\begin{array}{l}\text { D.W/solvent } \\
\text { concentration }\end{array}$} & \multicolumn{4}{|c|}{ Microwave extraction } \\
\hline & Absorbance & FRS & BHT & IC $50 \mu \mathrm{g} / \mathrm{ml}$ \\
\hline 0.1 & 0.253 & 50.69 & 78.37 & 0.0892 \\
\hline 0.2 & 0.205 & 61.86 & 79.53 & \\
\hline 0.3 & 0.167 & 70.69 & 81.86 & \\
\hline
\end{tabular}

DW: Distilled water, E: Ethanol, IC: Inhibition concentration, BHT: Butylated hydroxytoluene, FRS: Free-radical scavenging

Table 3: Free-radical scavenging ability CPS extract with E-solvent compared with the BHT and IC 50

\begin{tabular}{lcccc} 
E/solvent & \multicolumn{4}{c}{ Microwave extraction } \\
\cline { 2 - 5 } concentration & Absorbance & FRS & BHT & IC $50 \mu \mathrm{g} / \mathrm{ml}$ \\
\hline 0.1 & 0.286 & 79.86 & 88.05 & -0.77624 \\
0.2 & 0.262 & 81.83 & 91.73 & \\
0.3 & 0.204 & 86.57 & 92.30 & \\
\hline
\end{tabular}

DW: Distilled water, E: Ethanol, IC: Inhibition concentration, BHT: Butylated hydroxytoluene, FRS: Free-radical scavenging

to be more potent comparing to water. This result is in agreement with previous studies which reported ethanol extraction capacity superior to water in relation to free radical compound (Balaky et al., 2020) 
Balaky, et al.

Table 4: Diameter of zone inhibition and antibiotic against the microorganism tested in micro dilution assay

\begin{tabular}{|c|c|c|c|c|c|c|c|c|c|}
\hline \multirow[t]{3}{*}{ Organisms } & \multicolumn{6}{|c|}{ Zone of inhibition $(\mathrm{mm})$} & \multirow{2}{*}{\multicolumn{3}{|c|}{$\begin{array}{c}\text { Zone of inhibition }(\mathrm{mm}) \\
\text { Antibiotics }\end{array}$}} \\
\hline & \multicolumn{3}{|c|}{ Distilled water extract } & \multicolumn{3}{|c|}{ Ethanol extract } & & & \\
\hline & 50 & 70 & 100 & 50 & 70 & 100 & Eyr10 & AMP10 & CN10 \\
\hline Staphylococcus aureus (ATCC 29213) & 17.54 & 19.96 & 21.04 & N.Z & N.Z & N.Z & 11.60 & 12.83 & 16.90 \\
\hline Pseudomonas aeruginosa (ATCC 27853) & 15.41 & 16.28 & N.Z & N.Z & N.Z & N.Z & 16.45 & 10.59 & 10.19 \\
\hline Bacillus subtilis (ATCC 6633) & N.Z & N.Z & N.Z & N.Z & N.Z & N.Z & 11.37 & N.Z & 11.10 \\
\hline Enterococcus faecalis (ATCC 29212) & N.Z & N.Z & 16.76 & N.Z & 13.84 & N.Z & 13.14 & 7.80 & 10.71 \\
\hline Enterobacter aerogenes & N.Z & N.Z & 20.85 & N.Z & N.Z & 16.23 & 8.80 & 11.42 & 17.66 \\
\hline Klebsiella pneumonia (CCM 2318) & N.Z & N.Z & N.Z & N.Z & N.Z & N.Z & 12.98 & 12.64 & 14.21 \\
\hline
\end{tabular}

Z: Zone of inhibition, Antibiotic (Antimicrobial Agent): 1. Ampicillin AMP10, 3. Erythromycin (Eyr10) 4.Gentamyci (Ge) CN10; N.Z.: No zone of inhibition

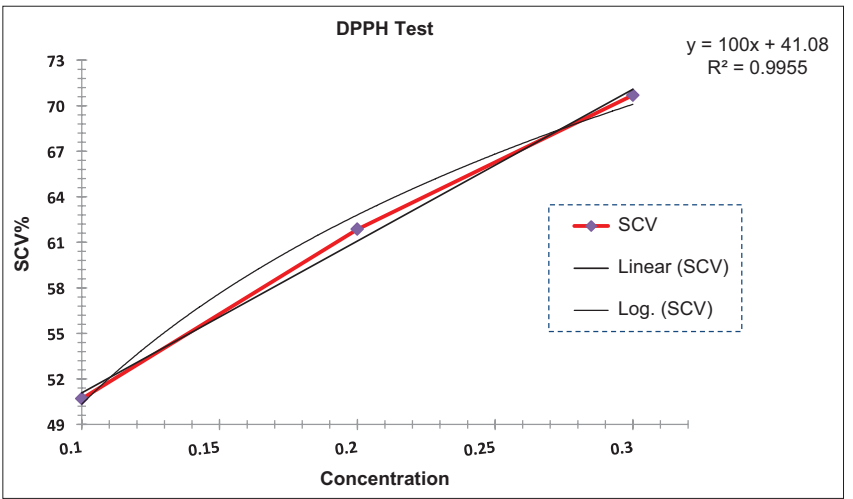

Figure 2: Free-radical scavenging activity, expressed as median inhibitory concentration $(\mu \mathrm{g} / \mathrm{ml})$ in the 1,1-diphenyl2-picrylhydrazyl test with chili pepper seed extracts against butylated hydroxyl toluene

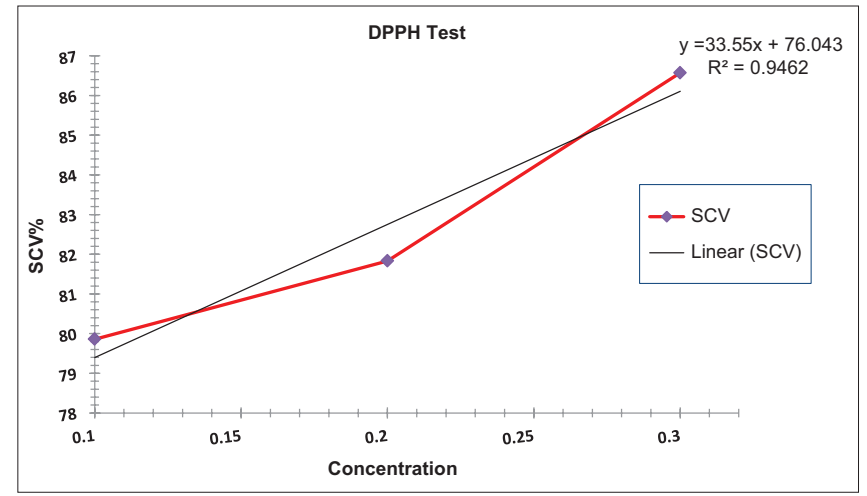

Figure 3: Free-radical scavenging ability of chili pepper seed with the ethanol solvent

\section{ANTIBACTERIAL ACTIVITY ASSESSMENT}

\section{Zone of Inhibition}

The antimicrobial activity of the seed extracts was examined depending on the diameter of growth inhibition zone comparing with commonly used antibiotics: Ampicillin, erythromycin, and gentamycin [Table 4]. The data showed that water extraction had higher antimicrobial activity comparing to ethanolic extraction. Furthermore, concentration 50,70, and $100 \mu \mathrm{g} / \mathrm{ml}$ inhibited growths of Staphylococcus by 17.54, 19.96, and $21.04(\mathrm{~mm})$, respectively, which is more than the tested standard antibiotics. Similarly,
Table 5: Determination of MIC in different extracts concentrations $(500,250,125,62,31,15,7.5,3.75$, and 0.9$)$ against bacteria strains

\begin{tabular}{lcc|} 
& \multicolumn{2}{c}{ Method/MW.W } \\
\cline { 2 - 3 } Organisms & $\begin{array}{c}\text { Water extract } \\
(\mu \mathrm{g} / \mathrm{ml})\end{array}$ & $\begin{array}{c}\text { Ethanol extract } \\
(\mu \mathrm{g} / \mathrm{ml})\end{array}$ \\
\hline $\begin{array}{l}\text { Staphylococcus aureus } \\
\text { (ATCC 29213) }\end{array}$ & 62 & - \\
$\begin{array}{l}\text { Pseudomonas aeruginosa } \\
\text { (ATCC 27853) }\end{array}$ & - & - \\
$\begin{array}{l}\text { Bacillus subtilis (ATCC 6633) } \\
\text { Enterococcus faecalis }\end{array}$ & - & - \\
$\begin{array}{l}\text { (ATCC 29212) } \\
\text { Enterobacter aerogenes }\end{array}$ & 250 & 125 \\
$\begin{array}{l}\text { Klebsiella pneumonia } \\
\text { (CCM 2318) }\end{array}$ & 31 & 250 \\
\hline
\end{tabular}

MIC=Minimum inhibition concentration. (-): no antibacterial activity

concentration $100 \mu \mathrm{g} / \mathrm{ml}$ of water extract could inhibit Enterococcus faecalis (ATCC 29212) and Enterobacter aerogenes with 16.76 and $20.85(\mathrm{~mm})$, respectively. Ethanol extraction concentration 70 and 100 could only inhibit $E$. faecalis and $E$. aerogenes to 13.84 and $16.23 \mathrm{~mm}$, respectively. It can be noticed that extraction with water was able to kill aforementioned bacteria better than antibiotics. Furthermore, it was seen that the most susceptible bacteria were Staphylococcus aureus (ATCC 29213) and Pseudomonas aeruginosa (ATCC 27853) which sometimes resist antibiotics. The plant antimicrobial activity may be associated with the presence of biologically active compounds that may inhibit the growth of bacteria (Holem et al., 2020; Galali et al., 2017). These results could be of particular interest since bacteria grow they cause septicemia enteritis due to production of toxins. Growth can various diseases due to production of toxins (Jurkštienè et al., 2011).

\section{MIC}

The MIC is the less concentration of an antimicrobial that prevents the visual growth of a microorganism after incubation for $24 \mathrm{~h}$ (Kaya et al., 2012). The data of (MIC) are shown in Table 5. It has been noticed that MIC of water extraction against $S$. aureus (ATCC 29213), E. faecalis (ATCC 29212), and E. aerogenes are 62, 250, and $31 \mu \mathrm{g} /$ $\mathrm{ml}$, respectively, on the other hand, MIC of the ethanol extract for E. faecalis (ATCC 29212) and E. aerogenes 125 and $250 \mu \mathrm{g} / \mathrm{ml}$, respectively. 


\section{CONCLUSIONS}

The study aimed to assess antioxidant and antimicrobial activities hot pepper seed oil extracts. Yield extraction and total anthocyanin values extracted with water were significantly higher than ethanolic extraction. Whereas total tannin, total phenol and total flavonoid values were significantly higher with ethanol extraction. Ethanol has the greater free radical scavenging and closer standard BHT. Whereas, the water extraction had broader antimicrobial activity. Therefore, CPS extracts particularly with water as a green and low cost solvent could be used as source of antimicrobial agent particularly against some bacteria like $S$. aureus and $P$. aeruginosa as well as antioxidants compounds with the use of suitable solvents and exposure to microwave obtaining good extract.

\section{REFERENCES}

Arslan, D. and M. M. Özcan. 2011. Dehydration of red bell-pepper (Capsicum annuum L.): Change in drying behavior, colour and antioxidant content. Food Bioprod. Proc. 89(4): 504-513.

Arvouet-Grand, A., B. Vennat, A. Pourrat and P. Legret. 1994. Standardization of propolis extract and identification of principal constituents. J. Pharm. Belgiq. 49(6): 462-468.

Balaky, H. H. and A. İnanç. 2014. Thermal stability of chlorophyll pigments in virgin olive oil. Kahramanmaras J. Nat. Sci. 17(2): 34-40.

Balaky, H. H., Y. Galali, A. A. Osman, E. Karaoğul., E. Altuntas, M. T. Uğuz, A. M. K. Galalaey and M. H. Alma. 2020. Evaluation of antioxidant and antimicrobial activities of mandarin Peel (Citrus reticulata blanco) with microwave assisted extract using two different solvents. Asian J. Plant Sci. 19(3): 223-229.

Chen, L., J. E. Hwang, K. M. Gu, J. H. Kim, B. Choi, K. S. Song, Y. Park and Y. H. Kang. 2012. Comparative study of antioxidant effects of five Korean varieties red pepper (Capsicum annuum L) extracts from various parts including placenta, stalk, and pericarp. Food Sci. Biotechnol. 21(3): 715-721.

Cruz, A. B., R. Cé Bella Cruz, B. Cruz, M. Kanegusuku, V. C. Filho, R. A. Yunes, F. Delle Monache and R. Niero. 2006. Antimicrobial activity of Rubus imperialis (Rosaceae). Acta Farm. Bonaerense. 25(2): 256-259.

Dewanto, V., W. Xianzhong, K. K. Adom and R. H. Liu. 2002. Thermal processing enhances the nutritional value of tomatoes by increasing total antioxidant activity. J. Agric. Food Chem. 50(10): 3010-3014.

Di Cagno, R., R. F. Surico, G. Minervini, M. De Angelis, C. G. Rizzello and M. Gobbetti. 2009. Use of autochthonous starters to ferment red and yellow peppers (Capsicum annum L.) to be stored at room temperature. Int. J. Food Microbiol. 130(2): 108-116.

Di Scala, K. and G. Crapiste. 2008. Drying kinetics and quality changes during drying of red pepper. LWT Food Sci. Technol. 41(5): 789-795.

Galali, Y., K. I. Aziz and S. Ali. 2017. The antimicrobial activity of peel and seeds extracts of red grapes. J. Tikrit Univ. Agric. Sci. 17(3): $36-40$.

Galali, Y., Z. A. Omar and S. M. Sajadi. 2020. Biologically active components in by-products of food processing. Food Sci. Nutr. 8(7): 1-19.
Gálvez, M., C. Martín-Cordero, P. J. Houghton and M. J. Ayuso. 2005. Antioxidant activity of Plantago bellardii all. Phytother. Res. 19(12): 1074-1076.

Gu, L. B., H. L. Pang, K. K. Lu, H. M. Liu, X. D. Wang and G. Y. Qin. 2017. Process optimization and characterization of fragrant oil from red pepper (Capsicum annuum L.) seed extracted by subcritical butane extraction. J. Sci. Food Agric. 97(6): 18941903.

Gülçin, İ., Z. Huyut, M. Elmastaş and H. Y. Aboul-Enein. 2010. Radical scavenging and antioxidant activity of tannic acid. Arab. J. Chem. 3(1): 43-53.

Hamad, H. O., M. H. Alma, I. Gulcin, M. A. Yilmaz and E. Karaoğul. 2017. Evaluation of phenolic contents and bioactivity of root and nutgall extracts from Iraqian Quercus infectoria olivier. Rec. Nat. Prod. 11(2): 205-210.

Holem, H. B., H. N. Rasul, A. K. Haval, S. Romel and B. Q. Ismael. 2020. Effect of heating on changes of chlorophyll content and oxidative stability in olive pomace oil. J. Crit. Rev. 7(19): 82828287.

Holem, H. B., K. M. Khalid, A. H. Hasan, S. M. Tahir, S. Ubur and K. Galalaey. 2021. Agriculture, environment and food sciences. Int J. Agric. Environ. Food Sci. 1(5): 1-6.

Jarret, R. L., I. J. Levy, T. L. Potter and S. C. Cermak. 2013. Seed oil and fatty acid composition in Capsicum spp. J. Food Comp. Anal. 30(2): 102-108.

Jinyan, W., W. Yuqi, Z. Lan and N. I. Shifeng. 2014. Kinetic study on extraction of red pepper seed oil with supercritical $\mathrm{CO}_{2}$. Chin. J. Chem. Eng. 22(1): 44-50.

Jurkštienè, V., A. Pavilonis, D. Garšvienè, A. Juozulynas, L. Samsonienè, D. Daukšienè, K. Jankauskienè, G. ŠimonienèKazlauskienè and E. Stankevičius. 2011. Investigation of the antimicrobial activity of rhaponticum (Rhaponticum carthamoides D.C. Iljin) and shrubby cinquefoil (Potentilla fruticosa L.). Medicina. 47(3): 24.

Kaya, O., F. Z. Akçam and G. Yayli. 2012. Investigation of the in vitro activities of various antibiotics against Brucella melitensis strains. Turk. J. Med. Sci. 42(1): 145-148.

Korkutata, N. F. and A. Kavaz. 2015. A comparative study of ascorbic acid and capsaicinoid contents in red hot peppers (Capsicum annum L.) grown in Southeastern anatolia region. Int. J. Food Propert. 18(4): 725-734.

Kothari, V., A. Gupta and M. Naraniwal. 2012. Comparative study of various methods for extraction of antioxidant and antibacterial compounds from plant seeds. J. Nat. Remedies, 12(2), 162-173.

Li, Y., S. Li, S. J. Lin, J. J. Zhang, C. N. Zhao and H. B. Li. 2017. Microwave-assisted extraction of natural antioxidants from the exotic gordonia axillaris fruit: Optimization and identification of phenolic compounds. Molecules. 22(9): 1481.

Makkar, H. P. S. and B. Singh. 1995. Determination of condensed tannins in complexes with fibre and proteins. J. Sci. Food Agric. 69(1): 129-132.

Medini, F., H. Fellah, R. Ksouri. and C. Abdelly. 2014. Total phenolic, flavonoid and tannin contents and antioxidant and antimicrobial activities of organic extracts of shoots of the plant Limonium delicatulum. J. Taibah Univ. Sci. 8(3): 216-224.

Murugan, R. and T. Parimelazhagan. 2014. Comparative evaluation of different extraction methods for antioxidant and antiinflammatory properties from Osbeckia parvifolia Arn.-an in vitro approach. J. King Saud Univ. Sci. 26(4): 267-275.

Omolo, M. A., Z. Z. Wong, A. K. Mergen, J. C. Hastings, N. C. Le, H. A. Reiland, K. A. Case and D. J. Baumler. 2014. Antimicrobial properties of chili peppers. J. Infect. Dis. Ther. 2(4): 2-8. 
Özyildiz, F., S. Karagönlü, G. Basal, A. Uzel and O. Bayraktar. 2012. Micro-encapsulation of ozonated red pepper seed oil with antimicrobial activity and application to nonwoven fabric. Lett. Appl. Microbiol. 56(3): 168-179.

Rapisarda, P., A. Tomaino, R. Lo Cascio, F. Bonina, A. De Pasquale and A. Saija. 1999. Antioxidant effectiveness as influenced by phenolic content of fresh orange juices. J. Agric. Food Chem. 47(11): 4718-4723.

Vega-Gálvez, A., K. Di Scala, K. Rodríguez, R. Lemus-Mondaca, M. Miranda, J. López and M. Perez-Won. 2009. Effect of airdrying temperature on physico-chemical properties, antioxidant capacity, colour and total phenolic content of red pepper (Capsicum annuum, L. var. Hungarian). Food Chem. 117(4): 647-653.

Wang, J., Y. Wang, L. Zheng, S. Ni, Z. Fan, R. Yao and K. Chen. 2014. Kinetic study on extraction of red pepper seed oil with supercritical $\mathrm{CO}_{2}$. Chin. J. Chem. Eng. 22(1): 44-50.

Xie, X., D. Zhu, W. Zhang, W. Huai, K. Wang, X. Huang, L. Zhou and H. Fan. 2017. Microwave-assisted aqueous two-phase extraction coupled with high performance liquid chromatography for simultaneous extraction and determination of four flavonoids in Crotalaria sessiliflora L. Ind. Crops Prod. 95: 632-642.

Yilmaz, E., E. Sevgi Arsunar, B. Aydeniz and O. Güneşer. 2015. Cold pressed capia pepperseed (Capsicum annuum L.) oils: Composition, aroma, and sensory properties. Eur. J. Lipid Sci. Technol. 117(7): 1016-1026.

Yilmaz, M. T. 2012. Minimum inhibitory and minimum bactericidal concentrations of boron compounds against several bacterial strains. Turk. J. Med. Sci. 42(2): 1423-1429.

Zou, Y., K. Ma and M. Tian. 2015. Chemical composition and nutritive value of hot pepper seed (Capsicum annuum) grown in Northeast region of China. Food Sci. Technol. 35(4): 659-663. 